\title{
Studies on Combining Ability and Heterosis for Yield and its Component Traits in Groundnut (Arachis hypogaea L.)
}

\section{A. Trivikrama Reddy ${ }^{1 *}$, M. Reddi Sekhar ${ }^{2}$, A. Vijayabharathi ${ }^{3}$, T. Lakshmi Pathy ${ }^{4}$,} G. Lakshmikantha Reddy ${ }^{2}$ and V. Jayalakshmi ${ }^{1}$

${ }^{1}$ Regional Agricultural Research Station, Nandyal - 518502, ANGRAU, Andhra Pradesh, India

${ }^{2}$ Department of Genetics and Plant Breeding, S.V. Agricultural College, Tirupati - 517502, Andhra Pradesh, India

${ }^{3}$ Department of Genetics and Plant Breeding, University of Agricultural Sciences, GKVK, Bangalore - 560065, Karnataka, India

${ }^{4}$ ICAR-Sugarcane Breeding Institute, Coimbatore, Tamil Nadu - 641007, India

*Corresponding author

\section{A B S T R A C T}

A half diallel cross involving six parental lines and their $15 \mathrm{~F}_{1}$ crosses (without reciprocals) were evaluated for combining ability of parents for 13 characters in groundnut. Variances due to sca were greater than that of gca indicating predominance of non-additive gene

\section{Keywords}

Groundnut, Diallel cross, Combining ability, Heterosis.

Article Info

Accepted:

07 October 2017

Available Online:

10 December 2017 action control on all the traits except days to maturity and plant height. The genotypes TCGS-29 and K-134 were found as good general combiners for kernel yield, pod yield per plant, mature pods per plant and 100-kernel weight while K-1238 was a good general combiner for shelling percentage, harvest index and percent pod set per plant, and Faizapur local for pegs per plant and pods per plant. Further, the most heterotic crosses identified in the study, involved either one or both good general combiners. Four heterotic crosses viz., K-134 × TCGS-29, TCGS-29 × K-1238, K-134 × K-1238 and TPT-4 × Local Red were emerged-out as good specific combiners for kernel yield per plant, pod yield per plant, mature pods per plant, pods per plant, pegs per plant, shelling percentage, 100-kernel weight, harvest index, percent pod set per plant and primary branches per plant. The cross combination TPT- $4 \times$ Faizapur Local was earlier to flower and mature with good sca effects. An attempt of inter-mating of selected plants in the advance generations of these five crosses is suggested to obtain transgressive segregants for pod and kernel yield in groundnut.

\section{Introduction}

Groundnut (Arachis hypogaea L.) is an important edible oil seed crop. The big gap in the productivity levels of India (991 Kg / ha) compared to USA (2863 Kg / ha) and China $(2645 \mathrm{Kg} / \mathrm{ha})$ is due to the lack of high yielding varieties suitable for rainfed condition responsive to fertilizers and improved agronomic practices in India. Tremendous genetic variation for pod yield and its components is available in the gene pool of groundnut which can be exploited for future. To bridge this yield gap, evolving new improved groundnut varieties are very much essential. In this context, the information on 
the combining ability of parents and the nature of gene action of yield its components would help in understanding the inheritance of characters, selection of suitable parents for hybridization and identification of promising early generation crosses so as to design an appropriate and efficient breeding strategy for further genetic improvement of groundnut genotypes.

\section{Materials and Methods}

The breeding material chosen for the present study comprised of six groundnut genotypes viz., K-134, TPT-4, Local Red, TCGS-29, K1238 and Faizapur Local that were selected as parents from distant clusters based on previous genetic divergence studies. Fifteen $\mathrm{F}_{1} \mathrm{~s}$ (excluding reciprocals) were produced through a diallel design involving these six parents. The evaluation of $15 \mathrm{~F}_{1} \mathrm{~s}$ along with their six parental genotypes was studied in randomized complete block design (RCBD) with three replications at the college Farm, S.V. Agricultural College, Tirupathi, Andhra Pradesh. Each cross was grown in three rows of $4.5 \mathrm{~m}$ length by adopting the spacing $30 \times$ $10 \mathrm{~cm}$. Observations were recorded on ten randomly selected competitive plants from each cross in each replication for 13 quantitative traits viz., primary branches per plant, days to $50 \%$ flowering, days to maturity, plant height, pegs per plant, mature pods per plant, per cent pod set, harvest index, shelling percentage, 100-kernel weight, pod yield per plant and kernel yield per plant. The combining ability analysis was carried out following the model $\mathrm{I}$ and method 2 of Griffing (1956).

\section{Results and Discussion}

Analysis of variance for combining ability revealed that the mean squares for both gca and sca were highly significant for all the characters except for plant height where mean squares for sca was non-significant. These results indicated the importance of both additive and non-additive gene effects (Table 1 ). The high ratio of gca: sca variances (more than unity) was recorded for days to maturity and plant height indicating that these characters were governed predominantly by additive component of heritable variance. The gca: sca ratios were less than unity for all other traits suggesting that these characters were governed predominantly by non-additive component. Similar kind of non-additive gene action was reported earlier for kernel yield per plant, pod yield per plant (Shoba et al., 2010, Gor et al., 2013, Prabhu et al., 2014 and Waghmode et al., 2017), primary branches per plant, pegs per plant, pods per plant (Jivani et al., 2009), mature pods per plant and 100-kernel weight (Shaik Nisar Ahmed, 1995, Ganesan et al., 2010), for shelling percentage (Kuchanur et al., 1997, Mothilal et al., 2010) and for pod yield (Makne et al., 1992, Dasaradha et al., 2004, Ganesan et al., 2010 and Mothilal et al., 2010). Similarly the importance of additive gene action in the inheritance of days to maturity was reported by Basu et al., (1987) whereas for plant height both additive and non-additive gene effects were reported by Habib et al., (1985). The estimates of gca effects recorded for the genotypes TCGS-29 and K-134 were found as good general combiners for kernel yield per plant, pod yield per plant and mature pods per plant (Table 2). Similarly, the genotype K1238 was found as good general combiner for shelling percentage, harvest index and percent pod set. Faizapur Local was identified as good combiner for pegs per plant and pods per plants while, Local Red and TCGS-29 were emerged-out as a good combiners for days to maturity, 100-kernel weight and plant height. The genotypes TPT-4 and TCGS-29 were also found to be good general combiners for early flowering and early maturity whereas K-1238 and TPT-4 for primary branches per plant. 
Table.1 Analysis of variance for combining ability for pod yield and its components in groundnut

\begin{tabular}{|c|c|c|c|c|c|c|}
\hline \multirow{2}{*}{ Character } & \multicolumn{3}{|c|}{ Mean sum of squares (MSS) } & \multirow{2}{*}{$\sigma^{2} g_{i}$} & \multirow{2}{*}{$\sigma^{2} s_{i j}$} & \multirow{2}{*}{$\sigma^{2} g_{i} / \sigma^{2} s_{i j}$} \\
\hline & $\operatorname{gca}(d f=5)$ & $\operatorname{sca}(d f=15)$ & Error & & & \\
\hline Primary branches per plant & $1.49 * *$ & $0.81 * *$ & 0.19 & 0.16 & 0.63 & 0.26 \\
\hline Days to $50 \%$ flowering & $0.46 * *$ & $0.31 *$ & 0.12 & 0.04 & 0.18 & 0.23 \\
\hline Days to maturity & $37.92 * *$ & $2.21 *$ & 1.07 & 4.6 & 1.12 & 4.09 \\
\hline Plant height & $22.66 * *$ & 2.37 & 1.65 & 2.63 & 0.72 & 3.66 \\
\hline Pegs per plant & $32.25 * *$ & $37.37 * *$ & 2.54 & 3.72 & 34.83 & 0.11 \\
\hline Pods per plant & $19.46 * *$ & $35.56 * *$ & 2.36 & 2.14 & 33.21 & 0.06 \\
\hline Mature pods per plant & $17.33 * *$ & $29.57 * *$ & 3.09 & 1.78 & 26.48 & 0.07 \\
\hline Percent pod set & $44.62 * *$ & $20.77 * *$ & 2.53 & 5.26 & 18.24 & 0.29 \\
\hline Harvest Index & $18.77 * *$ & $13.22 * *$ & 2.23 & 2.07 & 10.99 & 0.19 \\
\hline Shelling percentage & $21.68 * *$ & $10.23 * *$ & 2.89 & 2.34 & 7.34 & 0.32 \\
\hline 100-Kernel weight & $32.10 * *$ & $13.69 * *$ & 1.84 & 3.78 & 11.86 & 0.32 \\
\hline Pod yield per plant & $19.13 * *$ & $13.73 * *$ & 2.25 & 2.11 & 11.49 & 0.18 \\
\hline Kernel yield per plant & $11.90 * *$ & $8.44 * *$ & 0.78 & 1.39 & 7.66 & 0.18 \\
\hline
\end{tabular}


Table.2 General combining ability effects of six parents of groundnut for pod yield and its components

\begin{tabular}{|c|c|c|c|c|c|c|c|c|c|c|c|c|c|}
\hline Parents & $\begin{array}{c}\text { Primary } \\
\text { branches } \\
\text { per } \\
\text { plant } \\
\end{array}$ & $\begin{array}{c}\text { Days to } \\
50 \% \\
\text { flowering }\end{array}$ & $\begin{array}{l}\text { Days to } \\
\text { maturity }\end{array}$ & $\begin{array}{c}\text { Plant } \\
\text { height } \\
\text { (cm) }\end{array}$ & $\begin{array}{c}\text { Pegs } \\
\text { per } \\
\text { plant }\end{array}$ & $\begin{array}{c}\text { Pods } \\
\text { per } \\
\text { plant }\end{array}$ & $\begin{array}{c}\text { Mature } \\
\text { pods } \\
\text { per } \\
\text { plant } \\
\end{array}$ & $\begin{array}{c}\text { Per } \\
\text { cent } \\
\text { pods } \\
\text { set } \\
\end{array}$ & $\begin{array}{c}\text { Harvest } \\
\text { index }\end{array}$ & $\begin{array}{c}\text { Shelling } \\
\text { percentage }\end{array}$ & $\begin{array}{c}\text { 100- } \\
\text { kernel } \\
\text { weight }\end{array}$ & $\begin{array}{c}\text { Pod } \\
\text { yield } \\
\text { per } \\
\text { plant } \\
\end{array}$ & $\begin{array}{c}\text { Kernel } \\
\text { yield } \\
\text { per } \\
\text { plant } \\
\end{array}$ \\
\hline K-134 & $-0.31 *$ & $0.36 * *$ & $3.99 * *$ & - & $2.42 * *$ & 0.26 & 0.82 & $-3.46 * *$ & $1.77 * *$ & -0.41 & -0.71 & $1.08 *$ & $0.61 *$ \\
\hline TPT-4 & $0.32 *$ & $-0.35 * *$ & $-0.93 * *$ & -0.46 & 0.16 & -0.1 & 0.28 & -0.85 & 0.19 & -0.48 & $2.85 * *$ & -0.03 & -0.25 \\
\hline Local Red & -0.23 & -0.01 & $-2.10 * *$ & $1.13 * *$ & -0.75 & $-1.33 *$ & -1.1 & $-1.69 * *$ & $-2.47 * *$ & $-1.46 *$ & $-1.04 *$ & -0.15 & -0.57 \\
\hline TCGS-29 & $-0.53 * *$ & -0.1 & $-1.18 * *$ & $2.73 * *$ & 0.75 & $1.47 * *$ & $2.42 * *$ & $1.51 * *$ & -0.1 & $1.14 *$ & $1.96 * *$ & $2.20 * *$ & $2.07 * *$ \\
\hline K-1238 & $0.60 * *$ & 0.15 & -0.64 & $\begin{array}{c}- \\
1.30 * *\end{array}$ & $\begin{array}{c}- \\
3.51 * *\end{array}$ & $-2.16 * *$ & $-1.41 *$ & $2.33 * *$ & $1.37 * *$ & $2.63 * *$ & -0.57 & $-1.48 * *$ & -0.37 \\
\hline $\begin{array}{l}\text { Faizapur } \\
\text { Local }\end{array}$ & 0.17 & -0.06 & $0.86 *$ & -0.23 & 0.92 & $1.86 * *$ & -1.01 & $2.16 * *$ & -0.75 & $-1.41 *$ & $\begin{array}{c}- \\
2.49 * *\end{array}$ & $-1.62 * *$ & $-1.50 * *$ \\
\hline SE $\left(g_{i}\right)$ & 0.14 & 0.11 & 0.34 & 0.42 & 0.51 & 0.5 & 0.57 & 0.51 & 0.48 & 0.55 & 0.44 & 0.48 & 0.29 \\
\hline$P=0.05$ & 0.28 & 0.23 & 0.68 & 0.84 & 1.04 & 1 & 1.15 & 1.04 & 0.97 & 1.11 & 0.88 & 0.98 & 0.58 \\
\hline$P=0.01$ & 0.38 & 0.3 & 0.91 & 1.12 & 1.39 & 1.34 & 1.53 & 1.39 & $1.3-$ & 1.48 & 1.18 & 1.31 & 0.77 \\
\hline
\end{tabular}

* Significant at $P=0.05$

** Significant at $P=0.01$ 
Table.3 Specific combining ability effects of 15 crosses of groundnut for pod yield and its components

\begin{tabular}{|c|c|c|c|c|c|c|c|c|c|c|c|c|c|}
\hline Cross combination & $\begin{array}{c}\text { Primary } \\
\text { branche } \\
\text { s per } \\
\text { plant }\end{array}$ & $\begin{array}{c}\text { Days to } \\
\mathbf{5 0 \%} \\
\text { flowering }\end{array}$ & $\begin{array}{l}\text { Days to } \\
\text { maturity }\end{array}$ & $\begin{array}{c}\text { Plant } \\
\text { height } \\
(\mathrm{cm})\end{array}$ & $\begin{array}{c}\text { Pegs } \\
\text { per } \\
\text { plant }\end{array}$ & $\begin{array}{c}\text { Pods } \\
\text { per } \\
\text { plant }\end{array}$ & $\begin{array}{c}\text { Mature } \\
\text { pods per } \\
\text { plant }\end{array}$ & $\begin{array}{l}\text { Per cent } \\
\text { pods set }\end{array}$ & $\begin{array}{c}\text { Harves } \\
\text { t index }\end{array}$ & $\begin{array}{c}\text { Shelling } \\
\text { percentage }\end{array}$ & $\begin{array}{c}\text { 100- } \\
\text { kernel } \\
\text { weight }\end{array}$ & $\begin{array}{l}\text { Pod yield } \\
\text { per plant }\end{array}$ & $\begin{array}{c}\text { Kernel } \\
\text { yield per } \\
\text { plant }\end{array}$ \\
\hline K-134 × TPT- 4 & -0.31 & 0.35 & 1.02 & $2.44 *$ & $5.59 * *$ & $5.15^{* *}$ & $3.11 *$ & 1.87 & $-4.39 * *$ & -1.73 & $-2.04 *$ & 1.91 & 0.62 \\
\hline K-134 × Local Red & $0.76^{*}$ & -0.32 & 0.86 & -1.28 & $4.17 * *$ & 1.58 & -0.54 & $-2.58 *$ & -0.74 & -2.12 & 0.17 & $-2.30 *$ & $-2.16^{* *}$ \\
\hline K-134 × TCGS-29 & 0.23 & 0.1 & $1.61 *$ & 1.72 & $\begin{array}{c}11.20 * \\
*\end{array}$ & $\begin{array}{c}10.41 * \\
*\end{array}$ & $10.77 * *$ & 2.32 & 1.49 & -0.93 & -0.79 & $6.58 * *$ & $5.90 * *$ \\
\hline $\mathrm{K}-134 \times \mathrm{K}-1238$ & 0.21 & 0.18 & 1.40 & -1.85 & 0.26 & 0.61 & -1.97 & 0.39 & $5.43 * *$ & -1.41 & $2.57 *$ & 1.09 & 0.27 \\
\hline K-134 × Faizapur Local & 0.03 & 0.39 & -0.43 & $-2.45^{*}$ & $-3.09^{*}$ & $-4.14 * *$ & -0.57 & $-2.90 *$ & -0.69 & 1.66 & $4.33 * *$ & 0.97 & 0.93 \\
\hline TPT-4 × Local Red & $1.58 * *$ & -0.27 & -0.23 & $-2.09 *$ & $3.69 * *$ & 1.07 & 0.6 & $-3.66 * *$ & -0.35 & -2.05 & $4.82 * *$ & $3.55^{* * *}$ & $2.07 * *$ \\
\hline TPT-4 × TCGS-29 & $1.08 * *$ & 0.14 & -0.14 & 1.44 & $5.86 * *$ & $8.86^{* *}$ & $9.00 * *$ & $6.54 * *$ & $-3.15 * *$ & $-3.39 * *$ & -1.51 & -0.74 & $-1.81 * *$ \\
\hline ТРТ-4 × K-1238 & 0.02 & $-0.77 * *$ & 0.32 & -0.06 & -0.68 & -1.1 & -1.96 & -0.85 & -1.65 & -1.54 & -1.98 & -1.66 & $-1.57 *$ \\
\hline TPT-4 × Faizapur Local & 0.08 & -0.23 & $-2.85 * *$ & 1.27 & 1.03 & $2.88 *$ & -0.50 & $4.16^{* *}$ & 0.10 & 1.90 & $-2.49^{*}$ & 1.28 & $1.33 *$ \\
\hline Local Red_x TCGS-29 & $-0.77 *$ & 0.48 & 1.02 & 0.33 & $-3.07 *$ & $-3.77 * *$ & -0.91 & $-2.51 *$ & $5.37 * *$ & 0.45 & $2.20 *$ & $3.11 * *$ & $1.85 * *$ \\
\hline Local Red_× K-1238 & -0.44 & $0.56^{*}$ & -0.52 & 0.76 & $7.90 * *$ & $5.27 * *$ & $7.09 * *$ & $-3.14 *$ & $3.57 * *$ & 1.07 & 1.40 & 1.46 & $1.35^{*}$ \\
\hline Local Red_ $\times$ Faizapur Local & -0.11 & 0.10 & -1.02 & 0.55 & -1.36 & $3.78 * *$ & -0.85 & $9.33 * *$ & 0.12 & 2.41 & $-2.28^{*}$ & $2.57 *$ & $2.32 * *$ \\
\hline TCGS-29 × K-1238 & 0.50 & $-0.69 * *$ & 0.57 & -0.55 & -0.97 & 1.80 & 0.13 & $6.27 * *$ & 1.67 & $6.10 * *$ & $8.37 * *$ & $3.94 * *$ & $4.51 * *$ \\
\hline TCGS-29 × Faizapur Local & $1.23 * *$ & $-1.15 * *$ & -0.60 & -0.78 & 1.24 & 0.44 & 1.22 & -1.33 & $-4.85 * *$ & 0.47 & -0.34 & $-2.55^{* *}$ & $-1.32 *$ \\
\hline K-1238_x Faizapur Local & $0.77 *$ & -0.07 & 1.52 & 0.78 & $2.43 *$ & 0.81 & 1.79 & $-3.02 *$ & -0.35 & -0.91 & $-2.58^{*}$ & -1.74 & $-1.48^{*}$ \\
\hline $\mathrm{SE}\left(\mathrm{S}_{\mathrm{ij}}\right)$ & 0.32 & 0.25 & 0.76 & 0.94 & 1.17 & 1.12 & 1.29 & 1.16 & 1.09 & 1.24 & 0.99 & 1.10 & 0.65 \\
\hline $\mathrm{P}=0.05$ & 0.64 & 0.51 & 1.54 & 1.89 & 2.36 & 2.27 & 2.60 & 2.35 & 2.21 & 2.52 & 2.00 & 2.22 & 1.31 \\
\hline $\mathrm{P}=0.01$ & 0.86 & 0.69 & 2.06 & 2.54 & 3.15 & 3.04 & 3.40 & 3.15 & 2.96 & 3.37 & 2.68 & 2.97 & 1.75 \\
\hline
\end{tabular}


Table.4 List of best parents, best hybrids (on per se performance sca effects) and high heterotic crosses (over standard check)

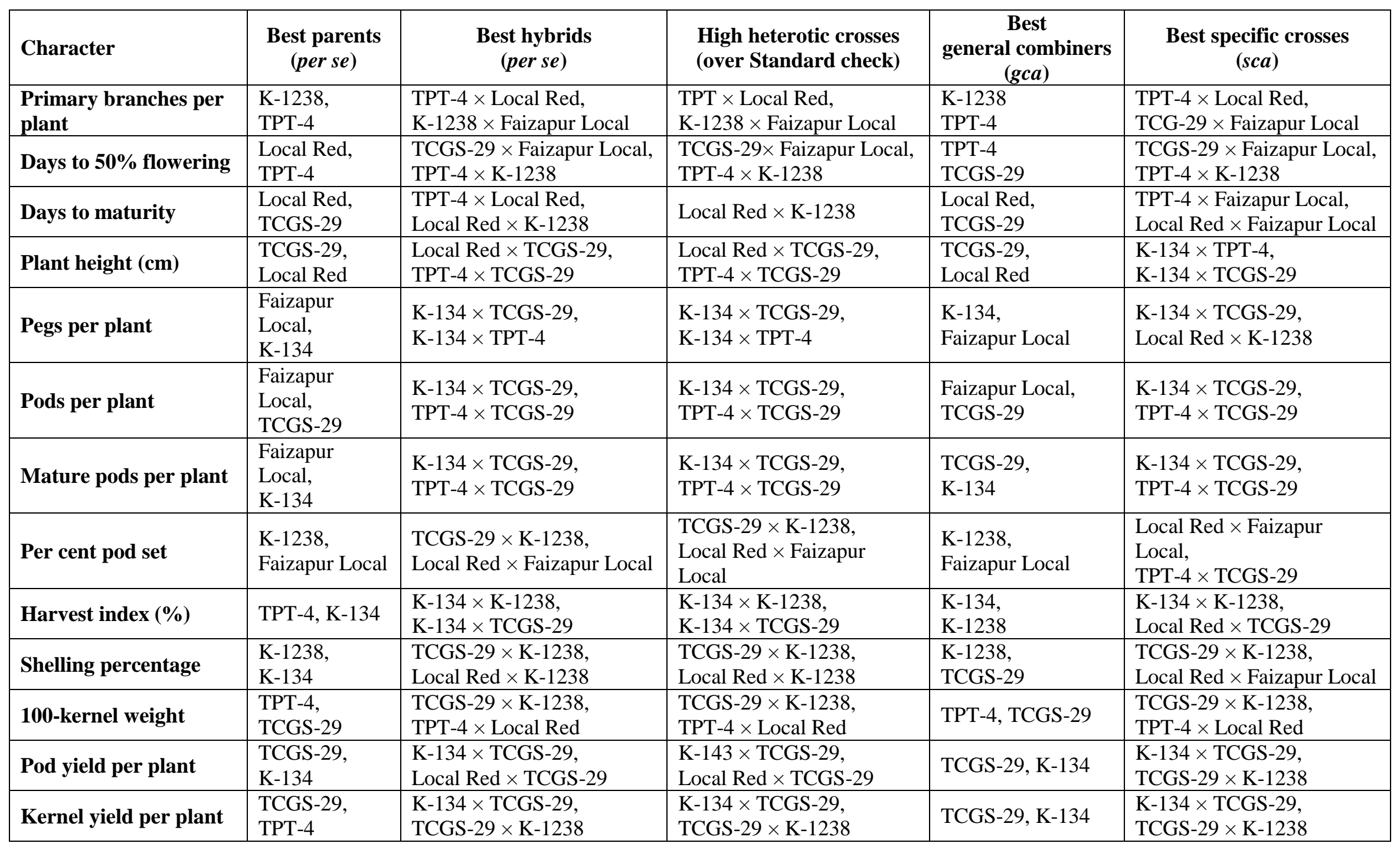


The $\mathrm{F}_{1}$ hybrids with significant sca effects for various traits are presented in Table 3. The cross K-134 $\times$ TCGS-29 showed significant sca effects for mature pods per plant, pod yield per plant and kernel yield per plant. The other best specific crosses identified were TCGS-29 × K-1238 for harvest index, TPT-4 $\times$ Faizapur Local for days to maturity, TCGS$29 \times$ Faizapur Local for days to $50 \%$ flowering, TPT $-4 \times$ Local Red for primary branches per plant and K-134 $\times$ TPT- 4 for plant height.

The best parents, and crosses (per se) good general combiners, specific combiners and heterotic crosses were furnished for pod yield and its components in Table 4. Among traits, in general, the highest significant standard heterosis estimates were observed for the characters kernel yield per plant, pod yield per plant, pegs per plant, pods per plant and mature pods per plant. The highest standard heterosis was expressed by the cross TCGS$29 \times$ K-1238 for shelling percentage and 100kernel weight by TCGS-29 $\times$ K-1238, for days to maturity by the cross TPT $-4 \times$ Faizapur Local, for primary branches per plant by the cross TPT $-4 \times$ Local Red and for plant height by the cross Local Red $\times$ TCGS29. The results obtained were similar to the findings of John et al., (2012) for primary branches; Jayalakshmi et al., (2000) for kernel yield per plant; Vindhiya Varman and Raveendran (1997), Gor et al., (2012) for pod yield per plant, mature pods per plant (Gor et $a l ., 2012$ ) and primary branches per plant and Manoharan (2002) for plant height and primary branches per plant.

Estimates of gca and sca effects showed that it was difficult to pick up a good general combiner for all the traits together. It is evident that the crosses which exhibited desirable sca effects involved parents with good, average and poor gca effects indicating the influence of non-additive gene actions in these crosses. Hence, the utility of bi-parental mating or inter-mating among selects in advanced generations is advocated for obtaining transgressive segregants for various economic traits. The $F_{1}$ hybrids with higher sca involving parents with good gca, can be further advanced through pedigree method of breeding for isolation of high yielding pure lines of groundnut.

Based on per se performance, sca effects and magnitude of standard heterosis, it is to concluded that five cross combinations viz., K-134 × TCGS-29, TCGS-29 × K-1238, TPT-4 $\times$ Local Red, Local Red $\times$ TCGS-29 and TPT- $4 \times$ TCGS-29 were identified as best specific crosses for isolating superior groundnut genotypes for good yield and its component characters.

\section{References}

Basu, M.S., Vaddoria, M.A., Singh, N.P. and Reddy, P.S. 1987. Combining ability for yield and its components in a diallel cross of groundnut. Indian J. Agric. Sci., 57: 82-84.

Boraiah, K.M., Shanker, G., Gejli, Kotreshi, Konda, C.R. and Prashanth, H.B. 2012. Heterosis for yield and yield attributing traits in groundnut (Arachis hypogaea L.). Legume Res., 35: 119-121.

Dasaradha, C., Reddy, R. and Suneetha, K. 2004. Combining ability and heterosis in groundnut (Arachis hypogaea L.). Proc. National symposium on enhancing productivity of groundnut for sustaining food and nutritional security, NRCG, Junagadh.

Ganesan, K. N., Paneerselvam, R. and Manivannan, N., 2010, Identification of crosses and good combiners for developing new genotypes in groundnut (Arachis hypogaea L.). Electronic J. Pl. Breed., 1: 167-172.

Gor, H.K., Dhaduk L.K. and Lata, R. 2013. 
Heterosis and inbreeding depression for pod yield and its components in groundnut (Arachis hypogaea L.). Electronic J. Plant Breed, 3(3): 868874.

Griffing, B. 1956. Concept of general and specific combining ability in relation to diallel crossing systems. Australian J. Biological Sci., 9: 463-493.

Jayalakshmi, V., Reddy, C.R., Reddy, P.V., Reddy, G.L. 2000. Characters association among morpho physiological attributes in parental genotypes and groundnut hybrids. Legume Res., 23: 102-105.

Jivani, L.L., Khanpara, M.D., Kachhadia, V.H. and Vachhani, J.H. 2009. Combining ability for pod yield and its components in groundnut (Arachis hypogaea L.). Int. J. Agril. Sci., 5: 248250.

John, K. and Vasanthi, R.P. 2006. Heterosis in six single crosses of groundnut (Arachis hypogaea L.). Legume Res., 29: 262-265.

John, K., Reddy, P.R., Reddy, K.H., Sudhakar, P. and Reddy, N. P. E. 2012b. Heterosis and inbreeding depression for vegetative traits in groundnut (Arachis hypogaea L.). Leg. Res., 35: 36-39.

John, K., Reddy, P.R., Reddy, K.H., Sudhakar, P. and Reddy, N.P.E. 2012a. Identification of best heterotic crosses for yield and water use efficiency traits in groundnut (Arachis hypogaea L.). J. Pl. Breed. Crop Sci., 4: 17-24.

John, K., Reddy, P.R., Reddy, K.H., Sudhakar, P. and Reddy, N.P.E. 2012. Heterosis and inbreeding depression for vegetative traits in groundnut (Arachis hypogaea L.). Leg. Res., 35: 36-39.

Kuchanur, P.H., Gowda, M.V. and Motagi, B.N. 1997. Combining ability of interspecific derivatives for improving resistance to late leaf spot and yield in groundnut (Arachis hypogaea L.). Karnataka J. Agric. Sci., 10(3): 713716.

Makne, V.G. 1992. Diallel analysis for studying the inheritance of branches, developed pods and harvest index in groundnut. J. Maharastra Agric. Univ., 17: $153-154$.

Manoharan, V. 2002. Heterosis for two vegetative characters in bunch groundnut (Arachis hypogaea L.). Madras Agricultural J., 89: (10-12): 709-712.

Mothilal, A. and Ezhil, A. 2010. Combining ability analysis for yield and its components in groundnut (Arachis hypogaea L.). Electronic J. Pl. Breed., 2: 162-166.

Prabhu, R., Manivannan, N., Mothilal, A. and Ibrahim, S.M. 2014. Combining ability analysis for yield and its component traits in groundnut (Arachis hypogaea L.) Electronic J. Plant Breed, 5(1): 3037.

Rudraswamy, P., Nehru, S.D., Kulkarni, R.S. and Manjunath, A. 1999. Estimation of genetic variability and inbreeding depression in six crosses of groundnut (Arachis hypogaea L.). Mysore J. Agric. Sci., 33(2): 248- 252.

Senthil, N. and Vindhiyavarman, P. 1998. Heterotic combinations of inter sub specific crosses of groundnut (Arachis hypogaea L). Annals Agric. Res., 19(4): 404- 406.

Shaik Nisar Ahamed, 1995. Heterosis, combining ability and interrelationships among yield and yield attributes in groundnut (Arachis hypogaea L.). M.Sc. (Ag.). Thesis submitted to the Andhra Pradesh Agricultural University, Hyderabad.

Shoba, D. N., Manivannan, N. and Vindhiyavarman, P. 2010. Gene effects of pod yield and its components in three crosses of groundnut (Arachis hypogaea 
L.). Electronic J. Plant Breed, 1(6):1415-1419.

Vindhiya Varman, P. and Raveendran, T.S. 1996. Genetic variability and casual relationship in groundnut. Madras Agric. J., 83(12): 784-786.

Vindhiya Varman, P. and Raveendran, T.S. 1997. Comparison of single and three way crosses in groundnut. Madras Agric. J., 83(12): 787-789.

Vyas, V., Nagda, A.K. and Sharma, S.P. 2001. Heterosis for pod yield and its components in groundnut (Arachis hypogaea L). Crop Res., 22(2): 267-
270.

Waghmode, B.D., Kore, A.B., Navhale, V.C., Sonone, N.G. and Thaware, B.L. 2017. Genetic Analysis of Promising Crosses and Good Combiners for Developing New Genotypes in Groundnut (Arachis hypogaea L.). Int. J. Curr. Microbiol. App. Sci., (2017) 6(7): 324-331.

Waghmode, S.U., Ubale, S.S., Suryavanshi, J.B., Gorde, B.B. and Parkhe, D.M. 2013. Studies on heterosis in groundnut (Arachis hypogaea L.). Bioinfolet, 10: 972-978.

\section{How to cite this article:}

Trivikrama Reddy, A., M. Reddi Sekhar, A. Vijayabharathi, T. Lakshmi Pathy, G. Lakshmikantha Reddy and Jayalakshmi, V. 2017. Studies on Combining Ability and Heterosis for Yield and its Component Traits in Groundnut (Arachis hypogaea L.). Int.J.Curr.Microbiol.App.Sci. 6(12): 551-559. doi: https://doi.org/10.20546/ijcmas.2017.612.067 